\title{
Logarytmiczny dekrement tłumienia w diagnostyce połączeń spawanych
}

\author{
Logarithmic damping decrement \\ in the diagnosis of welded joints
}

\section{Streszczenie}

W artykule przedstawiono metodę nieniszczących badań wibrodiagnostycznych do oceny połączeń spawanych, w której wykorzystano zmianę dekrementu tłumienia. Omówiono znaczenie monitoringu żywotności konstrukcji w konstrukcjach morskich. Otrzymane podczas realizacji badań odpowiedzi (zarejestrowane akcelerometrami) dostarczają informacji diagnostycznych, które wymagają matematycznego przetworzenia, aby wyodrębnić zapisane w nich istotne cechy charakterystyczne badanych połączeń spawanych i dokonać oceny ich jakości. W artykule przedstawiono metodę oceny wyników polegającą na obliczeniu dekrementu tłumienia, który zmienia się w czasie wraz ze zmianą odpowiedzi. Z uwagi na złożony przebieg odpowiedzi, dekrement tłumienia obliczono z wykorzystaniem aproksymacji odpowiedzi różnymi funkcjami.

Z analizy przeprowadzonych badań wynika, że zmiana dekrementu tłumienia w czasie w zastosowaniu do płyt spawanych pozwala na ocenę jakości połączenia spawanego. Omówiono istotne do realizacji badań połączeń spawanych metodą wibrodiagnostyczną elementy, przedstawiono algorytm obliczeniowy oraz przykładowe wyniki badań z aplikacji proponowanej metody dla płyty spawanej z różnymi wadami.

Słowa kluczowe: spawalnictwo; połączenia spawane; badania nieniszczące; wibrodiagnostyka NDT; SHM; dekrement tłumienia 


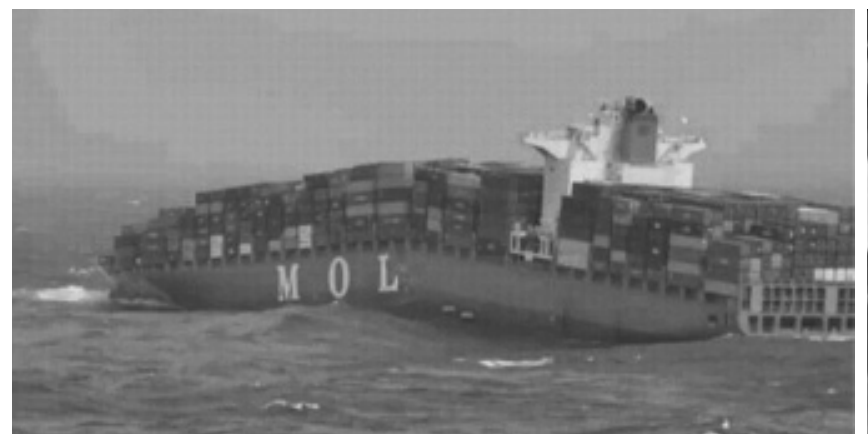

Rys. 1. Kontenerowiec złamany w wyniku silnego sztormu

Fig. 1. Container ship broken as a result of a strong storm

Połączenia spawane są jednym z kluczowych elementów, które są poddawane szczegółowym badaniom. Wszystkie odpowiedzialne spawy są badane przy pomocy technik pomiarowych określanych ogólnie NDT (ang. Non-Destructive Testing) [2,3]. Obecnie standardem badań NDT staje się stosowanie badań hybrydowych, które polegają na korzystaniu z metod mieszanych, łączących dwie lub więcej metod. Metody hybrydowe dzieli się na dwie grupy: wykorzystujące to samo zjawisko fizyczne oraz działające na zasadzie dopełnienia się poszczególnych metod badań. Przykładem metody hybrydowej zaliczanej do grupy wykorzystującej to samo zjawisko fizyczne jest połączenie emisji akustycznej z badaniami ultradźwiękowymi. Przykładem metody hybrydowej, działającej na zasadzie dopełnienia się poszczególnych metod badań, są badania powierzchniowe połączone z badaniami radiograficznymi i/lub ultradźwiękowymi $[1,4]$.

Techniki badań NDT są dobrze zbadane i dają rezultaty o zwykle wystarczającej niezawodności. Mają jednak podstawową wadę - przeprowadzane są okresowo. W okresach pomiędzy badaniami nie mamy pewności co do niezawodności konstrukcji [5]. Szczególnie w przypadku wystąpienia zdarzeń krytycznych (niezwykle silny sztorm, kolizja itp.) istotna jest informacja o możliwości dalszej eksploatacji obiektu. Informacja ta musi zawierać stopień zagrożenia katastrofą wraz z parametrami eksploatacji, włącznie z czasem jego bezpiecznego użytkowania. $W$ tym celu rozwijane są badania nad nowymi technikami określanymi z angielska jako SHM (ang. Structural Health Monitoring).

Monitoring żywotności konstrukcji jest naturalnym rozszerzeniem diagnostyki NDT maszyn i urządzeń. Monitoring jest interdyscyplinarną dziedziną badań, której celem jest rozwój i zastosowania praktyczne metod wykrywania i monitorowania uszkodzeń konstrukcji, poprzez system pomiarowy zintegrowany z badanym urządzeniem i działającym w sposób ciągły (on-line) oraz automatyczny. Monitoring może bazować na szeregu, czasem bardzo różnych, technik pomiarowych. Najbardziej obiecujące w warunkach morskich techniki to: metody bazujące na badaniu charakterystyk dynamicznych konstrukcji, emisji akustycznej, badaniu fal sprężystych typu „Lamb Waves” wraz z metoda spektralnych elementów skończonych, metody termowizyjne, ultraszybkie kamery obrazujące, warstwowym badaniu charakterystyk elektromagnetycznych, próżniowym badaniu porównawczym oraz metody bazujące na czujnikach światłowodowych. Celem systemów SHM jest zbudowanie układu pomiarowo-diagnozującego który byłby zdolny do oceny stanu technicznego konstrukcji w sposób ciągły i w różnych warunkach środowiskowych oraz eksploatacyjnych. Typowy system monitorowania żywotności konstrukcji jest złożony z sieci czujników, które mierzą w sposób ciągły stan konstrukcji oraz stan obciążeń środowiskowych i eksploatacyjnych. Jednostka centralna systemu ma za zadanie zbieranie i rejestrację sygnałów pomiarowych, ich analizę (wraz z selekcją) oraz automatyczną diagnostykę występujących zagrożeń $[6,7]$

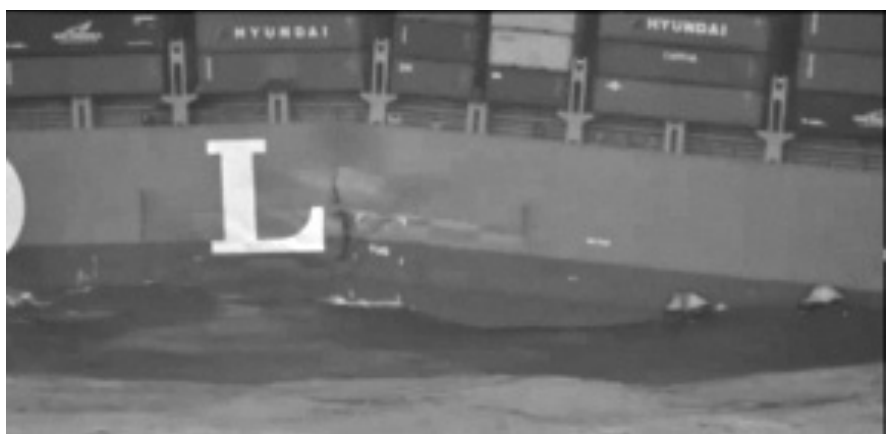

Prace nad elementami monitoringu konstrukcji polegającymi na detekcji, lokalizacji i identyfikacji uszkodzeń są intensywnie rozwijane, lecz najczęściej ograniczają się do badań laboratoryjnych i/lub wstępnych. Ponadto, prace na rzecz okrętownictwa są stosunkowo słabo rozwinięte (np. w stosunku do lotnictwa). Pełny monitoring to uzupełnienie systemów detekcji, lokalizacji i identyfikacji typu uszkodzenia o wiarygodne przewidywanie czasu żywotności konstrukcji oraz oceny możliwości jego dalszej, awaryjnej eksploatacji. W okrętownictwie brak jest uproszczonych, ale wiarygodnych, modeli matematycznych do oceny statyczno-dynamicznych, parametrów (istotnych z punktu widzenia niezawodności) pracy konstrukcji okrętowych. Modele te powinny być możliwe do zastosowania w systemach opartych na sztucznej inteligencji. Niezbędna jest ocena kluczowych elementów pomiarowych oraz ich efektywny dobór do takiego systemu [8].

Monitoring oparty na technikach wibrodiagnostycznych jest jednym z najbardziej obiecujących z uwagi na jego prostotę i relatywnie niskie koszty. Inne techniki nie znajdują na razie praktycznego zastosowania; przykładowo badania przy pomocy fal sprężystych wymagają niezwykle kosztownego sprzętu pomiarowego (np. laser 3-D) trudnego do zastosowania w warunkach eksploatacyjnych do tak złożonych konstrukcji, jakim jest kadłub statku $[9,10]$.

\section{Metoda i warunki pomiaru}

Na Wydziale Mechanicznym w Akademii Morskiej w Gdyni zbudowano stanowisko do przeprowadzania badań połączeń spawanych przy zastosowaniu metody wibrodiagnostycznej. Układ stanowiska i jego najważniejsze elementy przedstawiono na rysunku 2.

Podczas realizacji badań płyty były montowane w stojaku, w położeniu pionowym (jak przedstawiono to na rys. 2). Badania zostały przeprowadzono na czterech płytach. Jedna $z$ nich oznaczona została numerem „0" i była płytą bez połączeń spawanych. Trzy kolejne, były płytami spawanymi i oznaczono je następującymi numerami: 2202 - płyta nieposiadająca żadnych wad, 2127 - płyta z wadą typu przyklejenie brzegowe i 2132 - płyta z wadą typu pęknięciem na całej długości próbki.

Wszystkie próbki posiadające połączenia spawane zostały przed użyciem ich do pomiarów przebadane metodą radiograficzną (rys. 3). Pozwoliło to na ocenę jakości połączeń oraz umożliwiło identyfikację i umiejscowienie wad w płytach.

W przygotowanym stanowisku badawczym przeprowadzono pomiary drgań generowanych przez płyty. Drgania wywołane były przez uderzenie młotkiem modalnym z końcówką metalową. Miejsca uderzeń zostały przedstawione na rysunku 4 za pomocą oznaczeń: F1, F2 i F3. Wyniki były odczytane przez akcelerometry ACC1 i ACC2. 

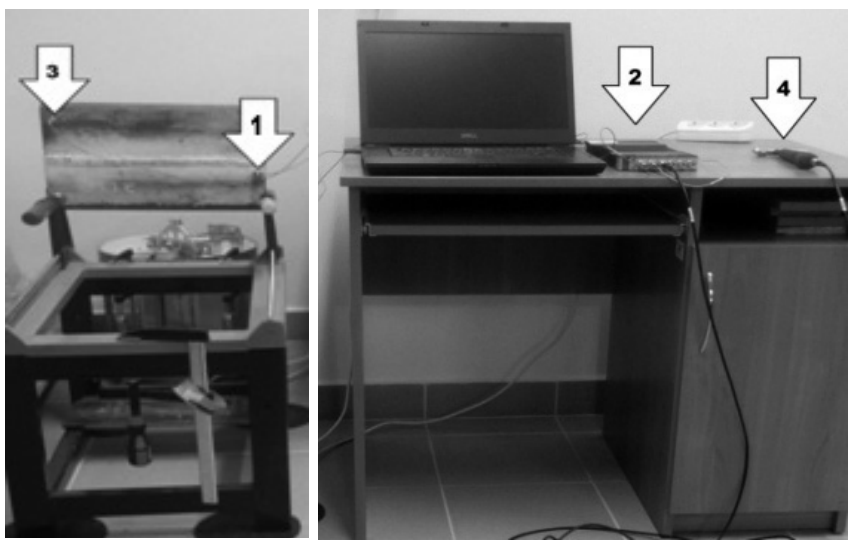

Rys. 2. Stanowisko do badań połączeń spawanych z wykorzystaniem metod drganiowych.

W skład stanowiska wchodzą: 1- stojak, w którym mogą być montowane płyty (próbki spawalnicze) w sposób poziomy - mocowanie czteropunktowe lub pionowy - mocowanie dwupunktowe, 2 - analizator drgań firmy Bruel \& Kjear typu 3050-A-60, 3 - akcelerometry 4514-B, 4 - młotek modalny (8206-002) z trzema wymiennymi końcówkami, tj. metalową, silikonową i teflonową.

Fig. 2. Stand for testing welded joints using vibration methods. The stand includes: 1 - rack, in which the plates (welding samples) can be mounted horizontally - four-point or vertical mounting - twopoint mounting, 2 - vibration analyzer Bruel \& Kjaer type 3050A-60, 3 - accelerometers 4514-B, 4 - modal hammer (8206-002) with three interchangeable tips, i.e. metal, silicone and teflon

\section{Dekrement tłumienia w ocenie połączeń spawanych}

W badaniu połączeń spawanych metodą wibrodiagnostyczną analizowane były odpowiedzi prędkości rozchodzenia się fal wzbudzonych młotkiem modalnym. Rejestrowane odpowiedzi mają charakter tłumionego przebiegu oscylacyjnego. Spaw, który łączy dwie płyty, obniża wartość amplitudy fali wzbudzonej młotkiem modalnym, dlatego też do jego oceny można wykorzystać dekrement tłumienia. Dekrement tłumienia jest powszechnie wykorzystywany w ocenie dynamiki wielu układów mechanicznych. Natomiast, ze względu na zmienny charakter odpowiedzi nie można zastosować typowego wzoru na logarytmiczny dekrement tłumienia, tylko należy go zaadoptować. W pracy przedstawiono dwie postacie logarytmicznego dekrementu tłumienia, które przedstawiono wzorami 1 i 2.

$$
\begin{gathered}
\Psi_{I}=\frac{1}{n} \cdot \ln \left(\frac{A_{0}}{A_{n}}\right) \\
\Psi_{I I}=\frac{1}{n-m} \cdot \ln \left(\frac{A_{m}}{A_{n}}\right)
\end{gathered}
$$

gdzie:

$\psi$ - logarytmiczny dekrement tłumienia,

$A_{0, n, m}$ - kolejne wartości szczytowe amplitud,

$\mathrm{n}, \mathrm{m}$ - kolejny numer amplitudy.

\section{Aproksymacja odpowiedzi z akcelerometrów}

W przypadku połączeń spawanych tłumione przebiegi oscylacyjne odpowiedzi rejestrowanych akcelerometrami charakteryzują się nierównomiernym rozkładem maksimów i minimów. Ze względu na zmienne zmiany prędkości drgań i potrzebę obliczenia dekrementu tłumienia zbadano możliwość a)

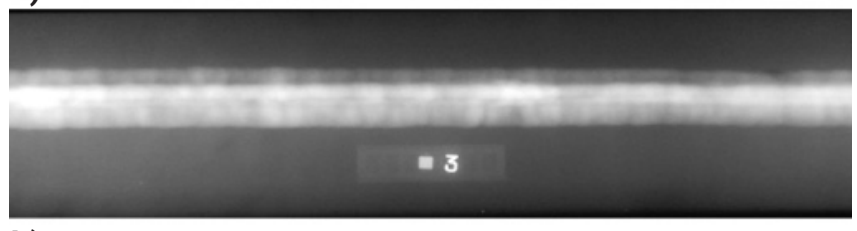

b)

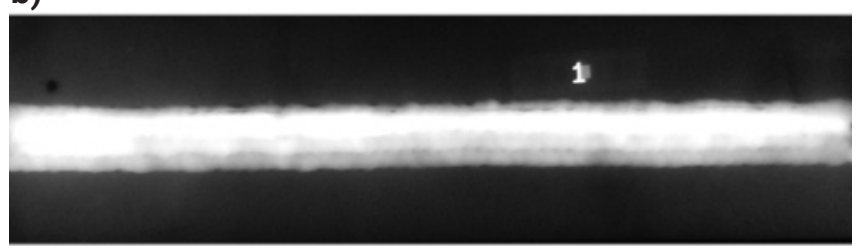

Rys. 3. Zdjęcie radiograficzne połączeń spawanych: a) płyta spawana bez wad w spoinie (2202), b) płyta spawana z wadą w spoinie typu przeklejenie brzegowe (2127)

Fig. 3. Radiographic image of welded joints: a) welded plate without defects in the weld (2202), b) welded plate with the lack of side fusion (2127)

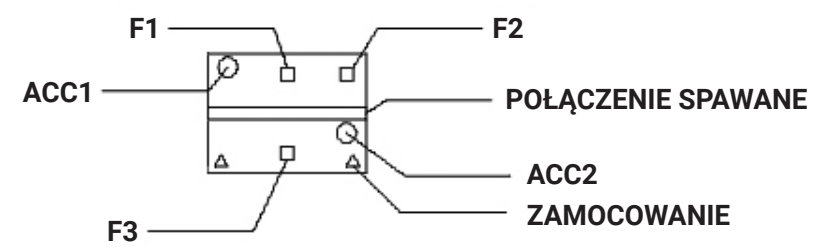

Rys. 4. Rysunek przedstawiający rozmieszenie akcelerometrów ACC1 i ACC2 w miejscach uderzeń: F1, F2, F3, oraz miejsca zamocowania płyty w uchwytach stojaka $(\Delta)[10]$

Fig. 4. Drawing shows the placement of ACC 1 and ACC2 accelerometers at the impact positions $F 1, F 2, F 3$, and the place where the plate is fixed in the rack holders $(\Delta)[10]$

aproksymacji przebiegu odpowiedzi za pomocą funkcji, które w ogólnej postaci przedstawiono wzorem (3).

W celu wyboru właściwej funkcji aproksymującej przeprowadzono ich analizę porównawczą, w której zestawiono aproksymacje otrzymane za pomocą wielomianów stopnia od drugiego do piątego oraz funkcję exp. Stopień dopasowania funkcji aproksymującej do danych rzeczywistych oceniono stosując współczynnik R - kwadrat, zwany też współczynnikiem determinacji. Jego wartość mieści się w przedziale od 0 do 1, gdzie wartość bliska 1 oznacza, że funkcja aproksymująca bardzo dobrze reprezentuje dane rzeczywiste, a wartość bliska 0, że jest odwrotnie, czyli funkcja aproksymująca bardzo słabo odwzorowuje dane rzeczywiste. Współczynnik R - kwadrat nie tylko został użyty do oceny dopasowania funkcji aproksymującej do danych rzeczywistych, ale również pozwolił porównać użyte funkcje między sobą.

$$
\begin{gathered}
v_{1}(t)=\sum_{i=0}^{N} a_{i} \cdot t^{i} \\
v_{2}(t)=b \cdot \exp (-c \cdot t)
\end{gathered}
$$

gdzie:

$v(\mathrm{t})$ _ funkcja aproksymująca przebieg prędkości,

$a_{i}$ - i-ta stała dla wielomianu,

b, c - stałe dla funkcji exp.

Na rysunkach 5 i 6 przedstawiono przykładowy wynik aproksymacji dla odpowiedzi zarejestrowanej dla próbki ze spawem bez wad i próbki z wadą w spawie typu przeklejnie brzegowe podczas przeprowadzenia badań z zastosowaniem końcówki metalowej na młotku modalnym.

Z porównania wyników aproksymacji wynika, że najgorszą wartość R - kwadrat otrzymano dla wielomianu kwadratowego, natomiast najlepszą wartość dla funkcji expotencjalnej. 


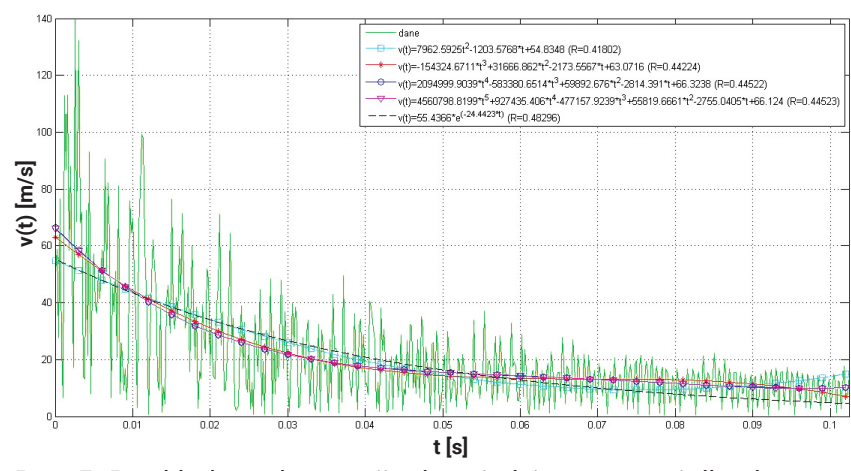

Rys. 5. Przykład aproksymacji odpowiedzi otrzymanej dla płyty spawanej bez wad w spoinie 2202 (końcówka metalowa)

Fig. 5. Example of approximation of the response obtained for a weIded plate without defects in the 2202 weld (metal tip)

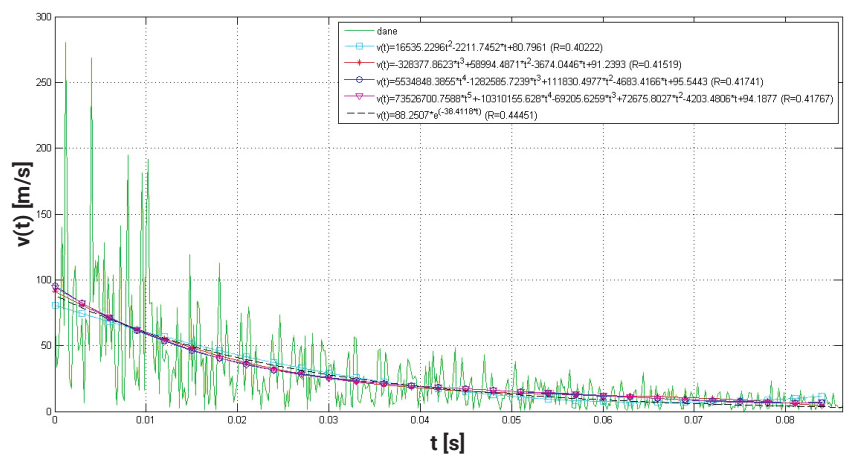

Rys. 6. Przykłady aproksymacji odpowiedzi otrzymanej dla płyty spawanej z wadą typu przyklejenie brzegowe 2127 (końcówka metalowa) Fig. 6. Examples of approximation of the response obtained for a welded plate with the lack of side fusion 2127 (metal tip)

Na podstawie współczynnika R - kwadrat widać również, że zadowalający wynik aproksymacji można uzyskać wielomianem czwartego stopnia natomiast zwiększanie stopnia wielomianu piątego nie przynosi już znaczącej poprawy aproksymacji.

\section{Zastosowanie rozkładu dekrementu do oceny połączeń spawanych}

Do obliczenia dekrementu tłumienia można wykorzystać wzory 1 i 2 . Na następnych rysunkach przedstawiono wyniki uzyskane dla pierwszego wzoru, natomiast w najbliższej przyszłości zamierza się sprawdzić zasadność stosowania drugiej możliwości. Pierwszy wzór pozwala na obliczenie rozkładu dekrementu tłumienia względem maksymalnej amplitudy, natomiast drugi względem wybranego zakresu.

Dla wyników otrzymanych z każdej funkcji aproksymującej obliczono wartość dekrementu tłumienia względem wartości maksymalnej $\left(A_{0}\right)$. Dekrement tłumienia uzyskany przy aproksymacji funkcją exp charakteryzuje się liniową zmianą i uznany został za referencyjny, ponieważ do jego wartości zostały odniesione pozostałe wyniki. Na rysunku 7 przedstawiono zmiany dekrementu tłumienia dla płyty bez połączenia spawanego przy różnych funkcjach aproksymujących. Jak widać, dla płyty bez połączenia spawanego rozkład dekrementu tłumienia jest zbliżony do równoległego, w stosunku do dekrementu uzyskanego na podstawie funkcji exp.

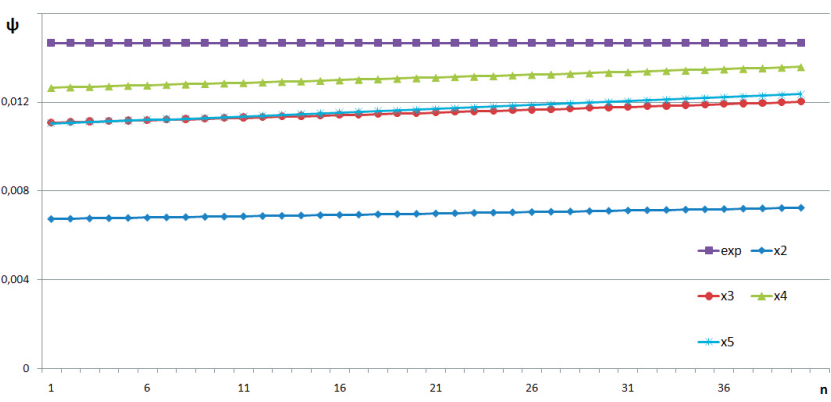

Rys. 7. Wartości zmian dekrementu tłumienia dla płyty bez spawu z zastosowaniem podczas badań końcówki metalowej na młotku modalnym (0)

Fig. 7. Values of damping decrement changes for a plate without a weld using a metal tip on the modal hammer during the tests (0)

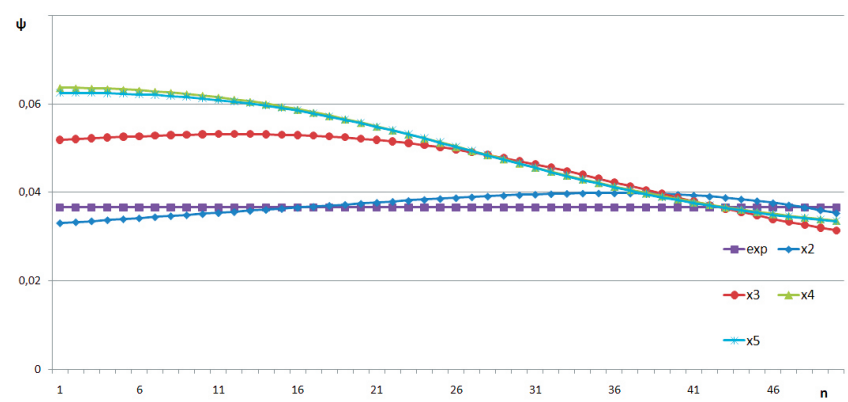

Rys. 8. Wartości zmian dekrementu tłumienia dla płyty ze spawem bez wad z zastosowaniem podczas badań końcówki metalowej na młotku modalnym (2202)

Fig. 8. Values of damping decrement changes for a plate with a nondefective weld using a metal tip on the modal hammer during the tests (2202)

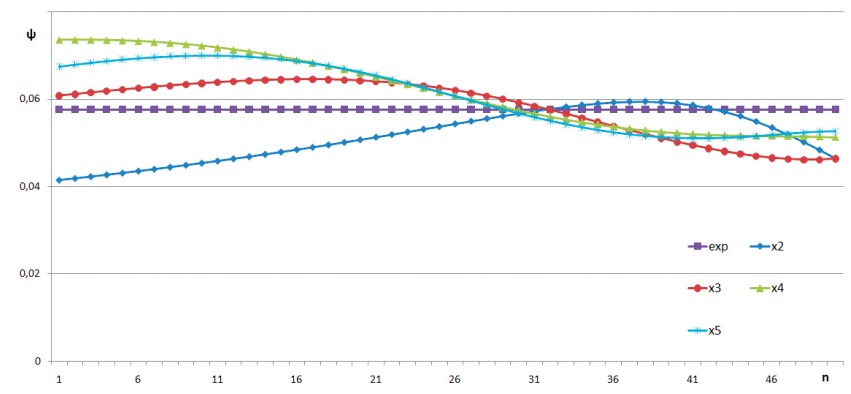

Rys. 9. Wartości zmian dekrementu tłumienia w czasie dla płyty ze spawem z niezgodnością typu przeklejnie brzegowe z zastosowaniem podczas badań końcówki metalowej na młotku modalnym (2127) Fig. 9. Values of the damping decrement changes in time for a plate with the lack of side fusion using a metal tip on the modal hammer during the tests (2127)

Świadczy to o równomiernym tłumieniu, które obserwuje się dla płyt wykonanych z jednego rodzaju materiału bez spawu.

Dla materiału z dobrym spawem można zaobserwować większe tłumienie (rys. 8). Dlatego przebiegi dekrementów ulegają wyraźnemu zakrzywieniu i stają się zbieżne do dekrementu obliczonego z funkcji exp. Do przecięcia z charakterystyką referencyjną dekrementu dochodzi przy 41 szczytowej amplitudzie odpowiedzi.

Dla płyty spawanej z wadą typu przeklejenie brzegowe efekt ten jest jeszcze bardziej zauważalny (rys. 9), ponieważ do przecięcia z charakterystyką referencyjną dekrementu doszło już przy 31 szczytowej amplitudzie odpowiedzi. 


\section{Wnioski}

Zaprezentowana metoda analizy odpowiedzi uzyskanej w badaniach wibrodiagnostycznych płyt spawanych pozwala wskazać na jakość spoin i rozróżnić wady, które w nich występują. Zgodnie z oczekiwaniami, dla płyty wykonanej z jednego materiału i pozbawionej spawu rozkład dekrementu tłumienia uzyskanego dla różnych funkcji aproksymujących jest praktycznie linowy i równoległy do charakterystyki dekrementu referencyjnego. W pozostałych przypadkach, tj. dla płyt z połączeniami spawanymi, charakterystyki dekrementu tłumienia wyraźnie się zakrzywiają i wykazują tendencję do przecinania z charakterystyką dekrementu referencyjnego. Z przeprowadzonych badań wynika, że charakterystyki dekrementu tłumienia zakrzywiają się szybciej dla płyt, w których spoina posiada wadę.

Zastosowanie do aproksymacji odpowiedzi różnych funkcji pozwoliło ocenić ich przydatność w wykonywanych obliczeniach. Z analizy porównawczej wyników uzyskanych dla wybranych funkcji widać, że nie powinno się stosować w tych obliczeniach wielomianu stopnia drugiego. Natomiast zwiększanie wielomianu powyżej stopnia czwartego też wydaje się być niezasadne, ponieważ wyniki się pokrywają. Jak pokazują charakterystyki, stosowanie wielomianu czwartego stopnia pozwala otrzymać niepełny wynik, który jest niższy od wyniku otrzymanego dla wielomianu czwartego stopnia.

Prezentowana metoda oceny połączeń spawanych podlega nadal modyfikacji i jest weryfikowana na większej liczbie próbek z różnymi wadami w połączeniach spawanych.

\section{Literatura}

[1] Bień J.: Uszkodzenia i diagnostyka obiektów mostowych, WKŁ, Warszawa 2010.

[2] Czurchryj J., Papkala H., Winiowski A.: Niezgodności w złączach spajanych, Instytut Spawalnictwa Gliwice 2005.

[3] Czuchryj J.: Badanie złączy spawanych wg norm europejskich. Systematyka i przyczyny postania wad w złączach spawanych, Biuro Gamma Warszawa 2003

[4] Krajewski A., Hudycz M.: Zapewnienie jakości i kontrola złączy spajanych, Oficyna Wydawnicza Politechniki Warszawskiej, Warszawa 2015.

[5] Lewicka-Romicka A.: Badania nieniszczące. Podstawy defektoskopii, Wydawnictwo Naukowo-Techniczne Warszawa 2001.

[6] Murawski L., Ostachowicz W., Opoka S., Mieloszyk M., Majewska K: Practical application of monitoring system based on optical sensors for marine constructions. Key Engineering Materials, Vol. 518, 2012.

[7] Opoka S., Murawski L., Wandowski T., Malinowski P., Ostachowicz W.: Static - Strain Level Change Together with Detection of Transient Signal as Damage Indicator for Truss and Fame Structures. Strain, Vol. 49 Issue 4, August 2013.

[8] Szeleziński A., Gesella G., Murawski L.: Przegląd metod diagnostyki i monitoringu połączeń spawanych $\mathrm{w}$ konstrukcjach transportu morskiego, Logistyka 3/2015.

[9] Szeleziński A., Murawski L., Muc A., Gesella G.: Badania wstępne możliwości diagnostyki połączeń spawanych przy pomocy analizy charakterystyk dynamicznych, Zeszyty Naukowe Akademii Morskiej w Gdyni nr 96/2016.

[10] Szeleziński A., Murawski L., Muc A.: Analysis of ability to detect defects in welding structures with usage of dynamic characteristics spectrums. Journal of KONES Powertrain and Transport, Vol. 23, No 2, European Science Society of Powertrain and Transport Publication, Warsaw 2016. 